\title{
The Impact of Two Types of Vocabulary Preparation on Listening Comprehension, Vocabulary Learning, and Vocabulary Learning Strategy Use
}

\author{
Mandana Hazrat \\ Payam -e- Noor University, Iran \\ Gholamreza Hessamy \\ Payam -e- Noor University, Iran
}

\begin{abstract}
Considering previous studies of the impact of vocabulary preparation before listening comprehension, this research investigated the impact of oral and written pushed output as two types of vocabulary preparation on listening comprehension, active and passive vocabulary learning, and vocabulary learning strategy use. Forty-one female adult Iranian EFL students at intermediate level participated in this study. As a treatment, they received two lists of new words which were learned separately through oral and written pushed output. This was followed by tests of active and passive vocabulary and listening comprehension. They also completed a vocabulary learning questionnaire before and after the treatment to detect any changes due to the treatment. We reached three pairs of scores for each participant including two active and two passive vocabulary test scores and two listening test scores for words treated through oral and written pushed output, separately. Statistical analyses indicated that vocabulary learning through oral pushed output was more effective in promoting listening comprehension and active vocabulary learning than vocabulary learning through written pushed output. Generally, vocabulary leaning through pushed output had a positive significant effect on vocabulary leaning strategy use. However, regarding passive vocabulary learning, the two types of treatment did not make any significant difference.
\end{abstract}

Index Terms —oral pushed output, written pushed output, vocabulary learning strategies

\section{INTRODUCTION}

In the past, vocabulary teaching and learning were not given much priority in second language programs. It was believed that vocabulary learning could look after itself during learning other language components (Richards \& Renandya, 2002). However, the changing overview of the status of vocabulary in language learning was mentioned by Meara (2002) who stated that vocabulary learning has moved a long way from being neglected in SLA to be a crucial component in language learning. The value of vocabulary instruction was also recognized. For instance, Esquiliche Mesa, Bruton, and Ridgway (2007; cited in Lee, 2008) underscored that vocabulary learning makes demands on learners. Therefore, it needs greater teacher's support than other aspects of language learning. Laufer (1998; cited in De la Fuente, 2002) also put emphasis on the importance of vocabulary instruction and the role of teachers in provision of scaffolding. She recognized that learners' passive vocabulary is more developed than their active vocabulary and attributed this to the lack of elicitation exercises. Based on the findings, she claimed that learners should be given exercises and tasks which elicit the newly taught vocabulary items to make them more willing to use new words in their production.

Similar idea which received both support and disagreement is persuading learners to produce vocabulary items or emphasizing the role of output for vocabulary learning. For instance, Nation (1995/96; cited in Richards \& Renandya, 2002) stressed that an essential aspect of vocabulary learning is learner's oral and written production. De la Fuente (2002) also refers to a study by Ellis and He (1999) as the first to provide evidence of the usefulness of output production for vocabulary acquisition. They found that learners who benefit output reached higher levels of both receptive and productive vocabulary learning. Henriksen (1999; cited in Lee, 2003) also argued for the importance of providing opportunity for the learners to actively use new words as a way of changing learner's receptive vocabulary into productive one.

However, different studies reached contradictory evidence about the usefulness of oral and written output. With respect to written output, while Barcroft (2004) mentioned the negative effect of sentence writing on vocabulary learning during initial stages of L2 lexical acquisition and Pressley, Levin, and Miller (1982; cited in Barcroft, 2004), and McDaniel and Kearney (1984; cited in Barcroft, 2004) found either no effect or even negative effect for sentence writing, Muncie (2002; cited in Lee, 2003) claimed that writing affects learners' vocabulary learning. Barcroft (2006) also found positive evidence for the impact of sentence writing on vocabulary learning. 
Regarding oral pushed output, De la Fuente (2002) concluded that it promotes vocabulary learning and retention. Lee (2003) made reference to a number of L2 studies that supported the effectiveness of promoting phonological memory for vocabulary learning such as Kelly (1992; cited in Lee, 2003) and Hill (1994; cited in Lee, 2003) who put emphasis on oral modeling of pronunciation and Ellis and Beaton (1993; cited in Lee, 2003), and Service and Kohonen (1995; cited in Lee, 2003) who mentioned the importance of repetition aloud. As stated by Nation (2001; cited in Chang, 2007), students should know the spoken form of the word. It means that they should be able to recognize the word when it is heard and be able to produce the form orally to express a meaning. According to Webb (2010), teaching learners the meaning and the pronunciation of the words is of great importance.

While previously mentioned findings demonstrated different viewpoints about oral and written output, Graves (1987; cited in Lawson \& Hogben, 1996) stressed the importance of encouraging learners to have personal plans for expanding their vocabulary. It is believed that students learn most of their vocabulary knowledge independently. Scholars such as Rossini Favretti, Silver, Gasser, and Tamburini (1994; cited in Lawson \& Hogben, 1996) endorsed the idea that EFL learners should develop autonomous learning strategies. Gu and Johnson (1996) posited that learners usually use variety of strategies together. They concluded that students adopt different types of strategies either in harmony with their beliefs about vocabulary and vocabulary learning (Abraham \& Vann, 1987; Horwitz, 1987; cited in Gu \& Johnson, 1996) or on the basis of congnitive and social factors. According to Sanaoui (1995; cited in Gu \& Johnson, 1996), what contributes to the outcome of L2 learning is the consistent use of specific types of strategies that forms an approach to vocabulary learning.

At the same time, vocabulary learning is not just important in its own right. As Richards and Renandya put it, nowadays, vocabulary has become an important component in language proficiency because without adequate vocabulary knowledge learners cannot take enough advantage of opportunities around them such as listening to radio, listening to native speakers, and watching television. In fact, vocabulary knowledge determines learners' ability in speaking, listening, reading, and writing (2002). Advocates of vocabulary instruction addressed the effect of vocabulary instruction on developing different skills. In a study conducted by Duin (1983; cited in Lee, 2003), the researcher found that explicit vocabulary instruction leads to greater use of appropriate words in writing which is the result of word awareness. As Lee (2003) mentions, the importance of vocabulary instruction in reading has been emphasized in the literature. However, as Chang (2007), Webb (2010), and Farrokhi and Modarres (2012) pointed out, there is lack of evidence in the area of the effectiveness of providing vocabulary pre-task activities before listening comprehension.

According to Chang (2007), understanding spoken English is certainly not easy for EFL learners. Although their common difficulties include limited vocabulary, fast speech rate, unfamiliar accent, and listening only once (Chang, 2007), as stated by Boyle (1984; cited in Chang, 2007), Chang and Read (2006; cited in Chang, 2007), Goh (2000; Farrokhi and Modarres, 2012), Kelly (1991; Farrokhi and Modarres, 2012), and Rost (1990; Farrokhi and Modarres, 2012), lack of vocabulary is one of the primary reasons for listening difficulties. Regarding the effect of vocabulary preparation on listening comprehension, researchers have reached different results. Some studies have argued for the effectiveness of vocabulary preparation. As an example, Webb (2010) investigated the effect of pre-learning vocabulary items on comprehension of television programs and incidental vocabulary learning through watching television. The result provided evidence in favor of pre-learning vocabulary. Widdowson (1983; cited in Farrokhi \& Modarres, 2012) also posited that providing vocabulary items before listening comprehension can compensate for lack of linguistic knowledge. However, other studies such as Chang and Read (2007) and Jensen and Hansen (1995; Farrokhi \& Modarres, 2012) doubted the effectiveness of vocabulary preparation.

Because of this conflicting evidence about the usefulness of providing vocabulary support before listening comprehension and also contradictory evidence regarding the usefulness of oral and written output for vocabulary learning, this study investigated the impact of two types of vocabulary preparation by posing the following questions:

1-Is vocabulary learning through oral pushed output more effective than vocabulary learning through written pushed output for improving listening comprehension ability?

2-Is vocabulary learning through oral pushed output more effective than vocabulary learning through written pushed output for active vocabulary learning?

3- Is vocabulary learning through oral pushed output more effective than vocabulary learning through written pushed output for passive vocabulary learning?

4- What is the effect of vocabulary learning through pushed output on vocabulary learning Strategy use?

\section{Methodology}

\section{Participants}

Participants of the study were 41 Iranian EFL students between the ages of 16 to 24 . They were female intermediate students studying general English in two different language institutes in Tehran. They were in four different classes taught by four teachers who were also responsible for data gathering procedures. Students participated in this study based on convenience or availability sampling. They were members of the classes that already existed in the institutes. All students who participated in this study underwent both types of treatments.

Instruments

The questionnaire. For eliciting participant's beliefs about vocabulary learning and vocabulary learning strategy use, 
a questionnaire based on the Vocabulary Learning Questionnaire (VLQ version 3), which was used in Gu and Johnson's (1996) study, was employed. The questionnaire contained eight major categories each having certain subcategories. Because administrating a questionnaire with 107 items was rather impractical and would probably reduce response validity, we reduced the number of items in the questionnaire by omitting those items that were unrelated to the objectives of this study and would not seem to be affected by the two types of treatments we had. More specifically, items related to dictionary strategies, guessing strategies, and note taking strategies were eliminated. Then, we had a 69-item questionnaire including sixteen subcategories. Because of the proficiency level of the students and in order to enhance the accuracy of the answers, the questionnaire was translated into Farsi. The answers were marked on a Likert scale with five points.

The listening test of homogeneity. Listening test No.4 from Cambridge IELTS 5 was used to check the homogeneity of the group.

Vocabulary checklist test. As a vocabulary pre-test to ensure that target words were unfamiliar to the participants, a vocabulary checklist test was administered. This form of test was used in previous studies by researchers such as Herman, Andersen, and Nagy (1987; cited in Henriksen, 1999), Nagy, Herman, and Andersen (1985; cited in Henriksen, 1999), and Rott (2007). Vocabulary checklist test provided a list of words for participants. The students were supposed to show their knowledge of vocabulary items by providing synonyms or translations for the given vocabulary items.

The active vocabulary test. In this test, students were given sentences with blanks. They were asked to fill in the blanks with suitable words the first letters of which were provided. According to Laufer (1998), the reason for provision of the first letter of the target words is to avoid the elicitation of non-target items which might fit the context of the sentences.

The passive vocabulary test. This test was in the form of matching items including target items and their dictionary definitions. Words were presented in groups of six or seven with three or four definitions in front of them. This form of test was also used in other studies such as Laufer (1998) and Laufer and Paribakht (1998).

The listening test. This test was based on Interchange video activity book by Zemach (2005). In fact, all the target words of this study were drawn from the texts related to the movies in this book. Participants were provided with some excerpts from these texts with blanks. They were supposed to watch the movies and fill in the blanks with target words they hear.

\section{Procedure}

Three instruments including the listening test of homogeneity, the questionnaire, and the vocabulary checklist test were used before the treatment. After the treatment, we used active and passive vocabulary tests, the listening test, and the questionnaire. Based on the result of the listening pretest, which was considered the test of homogeneity in our study, we ended up with 41 participants whose scores were within plus and minus two standard deviation of the mean. They formed the only group of participants in this study.

After the homogeneity test was run, we first piloted the questionnaire with 13 participants who had taken the listening homogeneity test and were chosen as our subjects. Students were supposed to answer the items of the questionnaire and circle any item which was unclear to them. Then, the circled items were modified considering some of the students' comments which were elicited in informal subsequent interviews conducted for this purpose.

Before the treatment, we administered the questionnaire to understand the students' initial attitudes toward vocabulary learning and their vocabulary learning strategies. Then, the vocabulary checklist tests were given to the subjects. Students received a list of words chosen from the texts in the Interchange video activity book which was part of their course syllabus. Participants had to demonstrate their knowledge of vocabulary items by providing Farsi translation or English synonym. They could skip the words they didn't know. After this stage, we ended up with 69 target words.

At this point we started the treatment. Target words were divided into two groups, 34 words for oral output group and 35 words for written output group. Each session students were presented with a list of ten words, five from one group and five from another one, accompanied by their dictionary definitions to be studied at home. The following session, they were supposed to make written sentences by the first five words which belonged to the written output group. These sentences were corrected by the teachers and given back to students the subsequent session. They also had to make oral sentences with the next five vocabulary items belonging to the oral output group. In this way, they both produced the items and heard the pronunciation of the items by others. Teachers corrected pronunciation errors.

At the end of the treatment sessions, we administered the tests. The first administered test was the active test because we did not want students to remember the words by looking at the options available in the passive test. In her study, De la Fuente (2002) also used the productive test before the receptive one to avoid a test effect. The active test had 69 fill-in-the-blank sentences including 34 words belonging to the oral output group and 35 words from the written output group. Consequently, we had two sets of scores for the active test which we called active oral output test and active written output test. After the active test, students took the passive test. Again, we had a 69-item test, 34 items of oral pushed output and 35 items of written pushed output. This time we distributed the papers of the exam in five different parts to the students because we did not want them to answer questions by looking at previous items and going through the process of deletion. Teachers were asked to collect each section of the papers when the students finished them and to distribute the next section. Again we arrived at two sets of scores, namely, for the passive oral output test and for the 
passive written output test. We administered both tests in one session.

The final test used was the listening test. We had four short movies and their total time was 27 minutes. Teachers were told to play movies twice to keep consistency. After the test, we separated the items of the two vocabulary groups and scored them separately. As a result, we ended up with two different sets of scores for the listening test which we called listening oral output scores and listening written output scores.

As a final step in data collection procedure, participants answered the questionnaire for a second time, but this time based on the ideas they had probably developed after both types of treatments, oral pushed output and written pushed output, to show how pushed output as a treatment generally affected participants' ideas about vocabulary learning and use of related strategies.

\section{The Scoring Procedure and Data Analysis}

Each item in the tests, including active, passive, and listening tests, had one point. We decided not to take into account grammatical mistakes. Spelling mistakes were also tolerated as far as they did not replace the word with another word indicating misunderstanding. Finally, we ended up with three pairs of scores for each student which were two active vocabulary scores, two passive vocabulary scores, and two listening test scores.

Paired-samples t-test was used to compare the mean score of the first and the second administration of the questionnaire and also for comparing the mean scores of two sets of the active vocabulary test, the passive vocabulary test, and the listening test.

\section{RESULTS AND ANALYSIS}

\section{Research Question 1}

The students showed higher mean score on the listening test for the oral pushed output items $(\mathrm{M}=21.95)$ than the items related to vocabulary learned through written pushed output $(\mathrm{M}=20.33)$. The results of the paired-samples t-test, as displayed in Table 1, reveal that the difference between the two means was statistically significant $(\mathrm{t}(40)=4.53, \mathrm{P}$ $=.000<.05, \mathrm{r}=.58)$. In fact, it showed a large effect size. The reliability indices $(\mathrm{K}-\mathrm{R} 21)$ for listening oral and listening written tests were .80 and .69 , respectively, which were acceptable for a teacher made test.

TABLE 1

PAIRED-SAMPLES T-TEST FOR LISTENING COMPREHENSION

\begin{tabular}{|c|c|c|c|c|c|c|c|c|}
\hline & \multicolumn{5}{|c|}{ Paired Differences } & \multirow[t]{3}{*}{$\mathrm{t}$} & \multirow[t]{3}{*}{ Df } & \multirow{3}{*}{$\begin{array}{l}\text { Sig. } \\
\text { (2-tailed) }\end{array}$} \\
\hline & \multirow[t]{2}{*}{ Mean } & \multirow[t]{2}{*}{$\begin{array}{l}\text { Std. } \\
\text { Deviation }\end{array}$} & \multirow[t]{2}{*}{$\begin{array}{l}\text { Std. Error } \\
\text { Mean }\end{array}$} & \multicolumn{2}{|c|}{$\begin{array}{l}\text { 95\% Confidence Interval of the } \\
\text { Difference }\end{array}$} & & & \\
\hline & & & & Lower & Upper & & & \\
\hline $\begin{array}{l}\text { LISTENINGORAL - } \\
\text { LISTENINGWRITTEN }\end{array}$ & 1.622 & 2.292 & .358 & .899 & 2.346 & 4.533 & 40 & .000 \\
\hline
\end{tabular}

\section{Research Question 2}

The students had higher mean scores on the active vocabulary test for the oral pushed output items $(M=23.15)$ than the items related to vocabulary learned through written pushed output $(M=21.75)$. The results depicted in Table 2 indicate that the difference between the two means was statistically significant $(\mathrm{t}(40)=3.07, \mathrm{P}=.000<.05, \mathrm{r}=.43$ ) and there was a moderate to large effect size. The reliability indices (K-R21) for active oral and active written tests were .84 and .79 respectively which were even higher than listening tests.

TABLE 2

PAIRED-SAMPLES T-TEST ACTIVE VOCABULARY LEARNING

\begin{tabular}{|c|c|c|c|c|c|c|c|c|}
\hline & \multicolumn{5}{|c|}{ Paired Differences } & \multirow[t]{3}{*}{$\mathrm{t}$} & \multirow[t]{3}{*}{ df } & \multirow{3}{*}{$\begin{array}{l}\text { Sig. } \\
\text { (2-tailed) }\end{array}$} \\
\hline & \multirow[t]{2}{*}{ Mean } & \multirow[t]{2}{*}{ Std. Deviation } & \multirow[t]{2}{*}{ Std. Error Mean } & \multicolumn{2}{|c|}{$95 \%$ Confidence Interval of the Difference } & & & \\
\hline & & & & Lower & Upper & & & \\
\hline $\begin{array}{l}\text { ACTIVEORAL - } \\
\text { ACTIVEWRITTEN }\end{array}$ & 1.396 & 2.936 & .459 & .469 & 2.323 & 3.044 & 40 & .004 \\
\hline
\end{tabular}

\section{Research Question 3}

The students' had slightly higher mean score on the passive vocabulary test for the written pushed output items $(\mathrm{M}=$ 27.97) than the items related to vocabulary learned through oral pushed output $(M=27.37)$. The results presented in Table 3 show that the difference between the two means is not statistically significant $(\mathrm{t}(40)=1.17, \mathrm{P}=.240>.05, \mathrm{r}$ $=.18)$. In fact, it represents a weak effect size. The reliability indices (K-R21) for passive oral and passive written tests were both .83 .

TABLE 3

PAIRED-SAMPLES T-TEST PASSIVE VOCABULARY LEARNING

\begin{tabular}{|c|c|c|c|c|c|c|c|c|}
\hline & \multicolumn{5}{|c|}{ Paired Differences } & \multirow[t]{3}{*}{$\mathrm{T}$} & \multirow[t]{3}{*}{ df } & \multirow{3}{*}{$\begin{array}{l}\text { Sig. } \\
\text { (2-tailed) }\end{array}$} \\
\hline & \multirow[t]{2}{*}{ Mean } & \multirow[t]{2}{*}{$\begin{array}{l}\text { Std. } \\
\text { Deviation }\end{array}$} & \multirow[t]{2}{*}{$\begin{array}{l}\text { Std. Error } \\
\text { Mean }\end{array}$} & \multicolumn{2}{|c|}{$\begin{array}{l}\text { 95\% Confidence Interval of } \\
\text { the Difference }\end{array}$} & & & \\
\hline & & & & Lower & Upper & & & \\
\hline $\begin{array}{l}\text { PASSIVEWRITTEN - } \\
\text { PASSIVEORAL }\end{array}$ & .599 & 3.278 & .512 & -.436 & 1.634 & 1.170 & 40 & .249 \\
\hline
\end{tabular}




\section{Research Question 4}

The students showed a slightly higher mean score for the posttest of strategy use $(\mathrm{M}=51.48)$ than the pretest $(\mathrm{M}=$ 49.82), indicating more use of strategies by the students after the treatments. The results shown in Table 4 indicate that the difference between the two means was statistically significant $(\mathrm{t}(40)=2.52, \mathrm{P}=.016<.05, \mathrm{r}=.37)$. It represents a moderate to strong effect size. The reliability indices (Cronbach's Alpha) for questionnaire pre-test and post-test were .692 and .523 respectively.

TABLE 4

PAIRED-SAMPLES T-TeST LEARNING STRATEgy USE

\begin{tabular}{|c|c|c|c|c|c|c|c|c|}
\hline & \multicolumn{5}{|c|}{ Paired Differences } & \multirow[t]{3}{*}{$\mathrm{T}$} & \multirow[t]{3}{*}{$\mathrm{df}$} & \multirow{3}{*}{$\begin{array}{l}\text { Sig. } \\
\text { (2-tailed) }\end{array}$} \\
\hline & \multirow[t]{2}{*}{ Mean } & \multirow[t]{2}{*}{$\begin{array}{l}\text { Std. } \\
\text { Deviation }\end{array}$} & \multirow[t]{2}{*}{$\begin{array}{l}\text { Std. Error } \\
\text { Mean }\end{array}$} & \multicolumn{2}{|c|}{$\begin{array}{l}\text { 95\% Confidence Interval of the } \\
\text { Difference }\end{array}$} & & & \\
\hline & & & & Lower & Upper & & & \\
\hline $\begin{array}{l}\text { Pretest of Strategy Use- } \\
\text { Posttest of Strategy Use }\end{array}$ & 1.666 & 4.227 & .660 & .332 & 3.000 & 2.524 & 40 & .016 \\
\hline
\end{tabular}

In order to have a more analytic view of the strategies tapped into in the questionnaire, its sixteen subcategories were separately considered by calculating the differences between the subjects' mean scores on different aspects of vocabulary learning strategy use before and after the treatment. The results are presented in Table 5.

TABLE 5

MEAN DIFFERENCES FOR THE QUESTIONNAIRE'S SUBCATEGORIES

\begin{tabular}{|l|l|}
\hline Categories & Mean differences \\
\hline Words should be memorized & .01 \\
\hline Words should be acquired in context & .29 \\
\hline Words should be studied and put to use & -.04 \\
\hline Selective attention & .21 \\
\hline Self-initiation & .21 \\
\hline Using word list & 0 \\
\hline Oral repetition & .69 \\
\hline Visual repetition & -.30 \\
\hline Association/Elaboration & .20 \\
\hline Imagery & .07 \\
\hline Visual encoding & .03 \\
\hline Auditory encoding & .51 \\
\hline Word structure & -.42 \\
\hline Semantic encoding & .14 \\
\hline Contextual encoding & -.06 \\
\hline Activation strategies & .20 \\
\hline
\end{tabular}

The results indicate an increase in the mean scores in most of the subcategories after the treatment such as words should be memorized, words should be acquired in context, selective attention, self-initiation, oral repetition, association, imagery, visual encoding, auditory encoding, semantic encoding, and activation strategies. It seems that participants showed more tendency toward applying these vocabulary learning strategies after the treatment. Among them, oral repetition shows the largest mean difference, followed by auditory encoding. The results may be because of participants' tendency toward oral practice of new vocabulary items in the form of repetition and paying more attention to pronunciation. From this group of strategies, the category related to word memorization indicates the smallest mean difference, so the treatment caused the minimum degree of improvement for this strategy.

On the other hand, some categories depicted a decrease in their mean scores after the treatment including words should be studied and put to use, visual repetition, word structure, and contextual encoding. Therefore, it may be true that the treatment changed the participants' viewpoints toward these types of vocabulary learning strategies in a negative way. In this group of strategies, the largest mean difference was found in word structure category. The second position belongs to visual repetition. As it appears, these two groups of strategies were most affected by the treatment negatively. In this group of strategies, the category of words should be studied and put to use had the smallest mean difference. Consequently, it can be said that this strategy was the least affected one by our treatments.

Other noticeable points can be detected. For instance, no change is indicated in using word list category. It seems that the treatment did not have any impact on learners' tendency toward this vocabulary learning strategy. Another point is the same mean difference in selective attention and self-initiation categories. It seems that they were affected by the treatment quite similarly.

\section{DISCUSSIONS AND CONCLUSIONS}

The results of analyses indicated that vocabulary learning through oral pushed output was more effective than vocabulary learning through written pushed output in promoting listening comprehension ability and active vocabulary learning. Furthermore, vocabulary learning through pushed output had a statistically significant effect on vocabulary learning strategy use. Although in the majority of the subcategories of strategy use it showed a positive effect, in some 
cases a negative effect was detected. However, there was no difference between vocabulary learning through oral pushed output and vocabulary learning through written pushed output in terms of their effect on passive vocabulary learning.

Taking into account the results of the study, we can compare them with other research findings along three lines. The first line can be the impact of providing vocabulary pre-listening activity on listening comprehension ability. The second is the effectiveness of oral and written pushed outputs for vocabulary learning. The last one can be the influence of pushed output on vocabulary learning strategy use.

With respect to the first line, our findings seem to be contrary to some research findings such as Elkhafaifi (2005) who conducted a study to evaluate the impact of pre-listening activities, including vocabulary preview or question preview and repeated listening input on students' listening comprehension scores. The results indicated that although the participants who engaged in either pre-listening activity scored higher than the control group, the participants who received the question preview outperformed those who received the vocabulary preview. Similarly, Berne (1995) underscored that participants who underwent question preview outperformed those who received vocabulary preview activity, but the difference was not found to be significant. She concluded that although vocabulary knowledge is essential for listening, studying vocabulary lists before listening may not be an influential way to improve listening comprehension ability. However, a difference is noticeable between her study and ours. In her study, as she stated, the vocabulary preview activity was passive because the subjects were just asked to read the words and their English equivalents. Consequently, the effectiveness of this activity was reduced. Berne suggested that more engaging vocabulary pre-listening activities such as brainstorming possible English equivalents of the items may be more effective. In our study, we tried to use an engaging vocabulary activity by making learners have oral and written outputs.

In a study by Chang and Read (2006; as cited in Vongpumivitch, 2007), the limited role of vocabulary teaching before listening was verified. They found that giving background knowledge of the topic and repeated input was more effective than giving vocabulary instruction and question preview. In fact, the worst performance belonged to the group who received vocabulary instruction. Therefore, according to Berne (1995), Chang (2005), and Chang and Read (2006), from different forms of support for facilitating listening comprehension, the impact of vocabulary support is less clear (all cited in Chang, 2008). According to Change (2008), the impact of vocabulary support on facilitating listening comprehension was not conclusive.

Following the second line of research which is related to the impact of pushed output on vocabulary learning, there is a dearth of previous research focusing on the impact of either oral or written output on vocabulary learning. Barcroft (2006) mentioned previous studies that led to mixed conclusions about the effects of sentence writing on vocabulary learning such as Coomber et al. (1986; as cited in Barcroft, 2006), Pressley et al. (1982; as cited in Barcroft, 2006), McDaniel and Kearney (1984), Barcroft (1998, 2000, 2004), and Folse (1999). With respect to oral production, research confirms the positive effect of oral practice on vocabulary learning. We can refer to De la Fuente (2002), Speciale et al. (2004), and $\mathrm{Hu}$ (2003) in this regard.

In the area of vocabulary learning strategy use, which is the third line of research to be discussed in relation to our findings, Gu and Johnson (1996), who wanted to establish the relationship between Chinese English learners' strategy use and outcomes in learning English in terms of vocabulary size and general proficiency, had findings comparable to the findings of this study. Although one of the focuses of our study was the impact of output on vocabulary learning strategy use, not on vocabulary size, we may be able to assume that participants in our study indicated tendency toward strategies which they found useful for increasing their vocabulary size as well. They found activation strategies and visual repetition as positive and negative predictors of vocabulary size, respectively. We reached similar findings in our research. In fact, our participants' viewpoints about these two types of strategies were positive and negative, respectively. Another point of similarity is the oral repetition strategy. Although Gu and Johnson stated its positive correlation with general proficiency not vocabulary learning, in our research it was one of the vocabulary learning strategies toward which learners had positive attitudes.

On the other hand, some of our results were found to be contrary to Gu and Johnson's (1996) findings. In our study, participants indicated negative attitudes toward word formation strategies and contextual encoding after the treatment, but in $\mathrm{Gu}$ and Johnson's study these two types of strategies were positively correlated with vocabulary size.

Based on the results, we can conclude that first, as stated before, there were previous studies which highlighted the ineffectiveness of vocabulary preparation before listening in comparison with other forms of pre-Listening activities. The reason might be the use of vocabulary preview activities which were passive in nature such as giving participants lists of words to study. In our study, the effectiveness of oral pushed output as a vocabulary preparation activity before listening may be due to engaging learners in an active process of oral production and drawing their attention to the sounds of the words through sound production and hearing others' pronunciation. Mastering the sounds of the words may be one of the essential requirements during listening comprehension. Therefore, according to our findings, it may be influential to use a vocabulary pre-listening activity which is not only engaging and active, but also based on production of sounds and pronunciation. On the other hand, the ineffectiveness of written pushed output before listening comprehension can be attributed to different modality and inconformity of written shape of the word and its pronunciation. 
Second, the usefulness of oral output for assisting the participants to develop active vocabulary, as supported by achieving higher scores in the active vocabulary test, may be the result of the powerful role of the phonological memory for word learning. Baddeley, Gathercole, and Papagno (1998; cited in Speciale et al., 2004) and Ellis (1996; cited in Speciale et al., 2004) also underscored the essential role of the phonological short-term memory in learning L2 words. Since developing active vocabulary knowledge or activating passive vocabulary has always been desirable, according to our findings, oral pushed output can be a plausible option in language instruction.

Third, participants' lower ability to use the knowledge of the words they gained through oral pushed output in the passive vocabulary test in comparison with the effective role of oral pushed output in active vocabulary learning may show that engaging participants in learning the shape of the word and making them write meaningful sentences without addressing its pronunciation is only useful for developing passive vocabulary knowledge. The reason may be that a passive vocabulary test is a matter of realizing the shape of the words and connecting them to their meaning, so oral modality of output does not seem more effective than its written modality to help learners in a passive vocabulary test. Therefore, applying oral and written output together seems to be a more reasonable procedure in the classroom.

Finally, regarding vocabulary learning strategy use, which was positively affected by output, it seems that output is successful in producing more strategic learners. Therefore, offering ways of vocabulary learning such as output which L2 learners find practical and their effectiveness are found to be obvious by the learners through experience may encourage learners to engage in the process of learning more insightfully and may motivate them to search for and experiment new ways of vocabulary learning. They may be encouraged to be more open-minded and welcoming to the new ways of vocabulary learning. It seems that this study provided further evidence for Swains' (1985) output hypothesis. It may be a good idea to implement pushed output in the classroom due to a number of reasons. For instructors, aside from providing variety in the classroom activities, implementing oral output tasks as a vocabulary pre-listening activity which can contribute to the learners' listening comprehension ability may be motivating for the learners because not reaching the desirable level in listening comprehension in spite of lots of efforts may demotivate learners. Aside from its motivating role, the engaging nature of the activity may convince instructors to decide to replace passive activities, which were found to be ineffective in previous studies, with more engaging activities such as output tasks if they want to provide pre-listening support for the learners. Instructors may also find it useful to accompany oral output with written output to enrich their instructions in order to make them suitable for the development of the learners' active and passive vocabulary knowledge simultaneously.

\section{REFERENCES}

[1] Abraham, R. G., \& Vann, R. J. (1987). Strategies of two language learners: A case study. In A. Wenden \& J. Rubin (Eds.), Learner strategies in language learning (pp. 85-102). Englewood Cliffs, NJ: Prentice- Hall.

[2] Baddeley, A. D., Gathercole, S., \& Papagno, C. (1998). The phonological loop as a language learning device. Psychological Review, 105, 158-173.

[3] Barcroft, J. (1998). L2 vocabulary learning: do sentence writing and oral repetition help? Poster Presentation at the Second Language Research Forum, Honolulu, HI.

[4] Barcroft, J. (2000). The Effects of sentence writing as semantic elaboration on the allocation of processing resources and second language lexical acquisition (Unpublished doctoral dissertation). University of Illinois, Urbana-Champaign.

[5] Barcroft, J. (2004). Effects of sentence writing in second language lexical acquisition. Second Language Research, 20(4), 303-334. doi: 10.1191/0267658304sr233oa.

[6] Barcroft, J. (2006). Can writing a new word detract from learning it? More negative effects of forced output during vocabulary learning. Second Language Research, 22(4), 487-497. doi: 10.1191/0267658306sr276oa.

[7] Berne, J.E. (1995). How do varying pre-listening activities affect second language listening comprehension? Hispania 78(2), 316-329.

[8] Boyle, J.P. (1984). Factors affecting listening comprehension. English Language Teaching Journal, 38, 34-38.

[9] Chang, C-S. (2005). The effects of test task characteristics on English listening comprehension and test-takers' perceptions. Journal of Hsing-Wu College, 29, 29-64.

[10] Chang, C-S. (2007). The impact of vocabulary preparation on L2 listening comprehension, confidence, and strategy use. System, 35, 534-550. doi:10.1016/j.system.2007.06.003.

[11] Chang, C.-S. (2008, Spring). Listening Strategies of L2 Learners with Varied Test Tasks. TESL Canada Journal, 25(2), 1-26.

[12] Chang, C-S., \& Read, J. (2006, June). The effects of listening support on the listening performance of EFL learners. TESOL quarterly, 40(2), 375-397. doi: 10.2307/40264527.

[13] Chang, C-S., \& Read, J. (2007). Support for foreign language listeners: Its effectiveness and limitations. RELC journal, 38(3), 375-394. doi: 10.1177/0033688207085853.

[14] Coomber, J.E., Ramstad, D.A., \&Sheets, D.R. (1986). Elaboration in vocabulary learning: A comparison of three rehearsal methods. Research in the Teaching of English, 20, 281-93.

[15] De la Fuente, M. J. (2002). Negotiation and oral acquisition of L2 vocabulary: The role of input and output in the receptive and productive acquisition of words. Studies in Second Language Acquisition, 24, 81-112.

[16] Duin, A. L. (1983). Effects of intensive writing instruction on a specific writing task (Unpublished Master's thesis). University of Minnesota, Minneapolis.

[17] Elkhafaifi, H. (2005). The effect of pre-listening activities on listening comprehension in Arabic learners. Foreign Language Annals, 38(4), 505-513.

[18] Ellis, N. C. (1996). Sequencing in SLA: Phonological memory, chunking and points of order. Studies in Second Language 
Acquisition, 18, 91-126.

[19] Ellis, N.C., \& Beaton, A. (1993). Psycholinguistic determinants of foreign language vocabulary learning. Quarterly Journal of Experimental Psychology, 46A, 533-558.

[20] Ellis, R., \& He, X. (1999). The role of modified input and output in the incidental acquisition of word meaning. Studies in Second Language Acquisition, 21, 285-301.

[21] Esquiliche Mesa, R., Bruton, A., \& Ridgway, T. (2007). The effect of task based reading on FL vocabulary learning. ITL International Journal of Applied Linguistics, 153, 1-24.

[22] Farrokhi, F., \& Modarres, V. (2012, January). The effects of two pre-task activities on improvement of Iranian EFL learners' listening comprehension. Theory and Practice in Language Studies, 2(1), 144-150. doi:10.4304/tpls.2.1.144-150.

[23] Folse, K.S. (1999). The effect of type of written practice activity on second language vocabulary retention (Unpublished doctoral dissertation). University of South Florida, Florida.

[24] Goh, C. C. M. (2000). A cognitive perspective on language learners' listening comprehension problems. System, 28, 55-75. doi: 10.1016/S0346-251X(99)00060-3.

[25] Graves, M. F. (1987). The roles of instruction in fostering vocabulary development. In M. G. McKeown \& M. E. Curtis (Eds.). The nature of vocabulary acquisition (pp. 165-184). Hillsdale, NJ: Erlbaum.

[26] Gu, Y., \& Johnson, R. K. (1996, December). Vocabulary learning strategies and language learning outcomes. Language Learning, 46 (4), 643-679.

[27] Henriksen, B. (1999). Three dimension of vocabulary development. Studies in Second Language Acquisition, 21, $303-317$.

[28] Herman, P., Anderson, R., \& Nagy, W. (1987). Incidental acquisition of word meaning from expositions with varied text features. Reading Research Quarterly, 22, 263-284.

[29] Hill, M. (1994). A word in your ear: to what extent does hearing a new word help learners to remember it? In N. Bird, P. Palvey, A.B.M. Taui, D.M. Allison, A. McNeill, \& R. J. Webb (Eds.), Language Learning (pp. 447-462). Hong Kong, China: Hong Kong Institute of Language Learning in Education.

[30] Horwitz, E. K. (1987). Surveying student beliefs about language learning. In A. Wenden \& J. Rubin (Eds.), Learner strategies in language learning (pp. 119- 129). Englewood Cliffs, NJ: Prentice- Hall.

[31] Hu, C.-F. (2003, September). Phonological memory, phonological awareness, and foreign language word learning. Language learning, 53(3), 429-462.

[32] Jensen, C., \& Hansen, C. (1995). The effect of prior knowledge on EAP listening-test performance. Language Testing, 12 (1), 99-119.

[33] Kelly, P. (1991). Lexical ignorance: The main obstacle to listening comprehension with advanced foreign language learners. International Review of Applied Linguistics in Language Teaching, 29(2), 135-149.

[34] Kelly, R. (1992). Does the ear assist the eye in the long-term retention of lexis? International Review of Applied linguistics in Language Teaching, 30, 137-145.

[35] Laufer, B. (1998). The development of passive and active vocabulary in a second language: Same or different? Applied linguistics, 19(2), 255-271.

[36] Laufer, B., \& Paribakht, T. S. (1998, September). The relationship between passive and active vocabulary: effects of language learning context. Language Learning, 48(3), 365-391.

[37] Lawson, M.J., \& Hogben, D. (1996, March). The vocabulary-learning strategies of foreign-language students. Language Learning, 46(1), 101-135.

[38] Lee, S.H. (2003). ESL learners' vocabulary use in writing and the effects of explicit vocabulary instruction. System, 31, 537-561. doi: 10.1016/j.system.2003.02.004.

[39] Lee, S. H. (2008). Beyond reading and proficiency assessment: The rational cloze procedure as stimulus for integrated reading, writing, and vocabulary instruction and teacher-student interaction in ESL. System, 36, 642-660.

[40] McDaniel, M.A., \& Kearney, E.M. (1984). Optimal learning strategies and their spontaneous use: the importance of task-appropriate processing. Memory and Cognition, 12, 361-73.

[41] Meara, P. (2002). Review article: The rediscovery of vocabulary. Second Language Research, 18(4), 393-407. doi: $10.1191 / 0267658302 \mathrm{sr} 211 \mathrm{x}$.

[42] Muncie, J. (2002). Process writing and vocabulary development: comparing lexical frequency profiles across drafts. System, 30, $225-235$.

[43] Nagy, W. E., Herman, P., \& Anderson, R. C. (1985). Learning words from contexts. Reading Research Quarterly, 20, $233-253$.

[44] Nation, P. (1995/96). Best practice in vocabulary teaching and learning. In J.C. Richards \&W.A. Renandya (Eds.), Methodology in language teaching: An anthology of current practice (pp. 267-272). Cambridge, U.K: Cambridge University Press.

[45] Nation, P. (2001). Learning vocabulary in another language. Cambridge, U.K: Cambridge University Press.

[46] Pressley, M., Levin, J.R., \& Miller, G.E. (1982). The keyword method compared to alternative vocabulary-learning strategies. Contemporary Educational Psychology, 7, 50-60.

[47] Richards, J.C., \& Renandya, W.A. (Eds.). (2002). Methodology in language teaching: An anthology of current practice. Cambridge, United Kingdom: Cambridge University Press.

[48] Rossini Favretti, R., Silver, M., Grasser, R., \& Tamburini, F. (Eds.). (1994). The self-access facility in a language centre. Bologna, Italy: Centro Interfacolta di Linguistica Teorica e Applicata.

[49] Rost, M. (1990). Listening in language learning. London, U.K: Longman.

[50] Rott, S. (2007, June). The effect of frequency of input enhancements on word learning and text comprehension. Language Learning, 57(2), 165-199.

[51] Sanaoui, R. (1995). Adult learners' approaches to learning vocabulary in second language. Modern Language Journal, 79, $15-28$.

[52] Service, E., \& Kohonen, V. (1995). Is the relation between phonological and foreign language learning accounted for by vocabulary acquisition? Applied Psycholinguistics 16, 155-172.

[53] Speciale, G., Ellis, N.C., \& Bywater, T. (2004). Phonological sequence learning and short- Term store capacity determine 
second language vocabulary acquisition. Applied psycholinguistics, 25, 293-321. doi: 10.1017.S0142716404001146.

[54] Swain, M. (1985). Communicative competence: Some roles of comprehensible input and comprehensible output in its development. In S. Gass \& C. Madden (Eds.), Input in second language acquisition (pp. 235-253). Rowley, MA: Newbury House.

[55] Vongpumivitch, V. (2007, Autumn). Research on EFL Listening Assessment in Taiwan: Current Issues and Future Directions. English Teaching \& Learning, 31(3), 63-100.

[56] Webb, S. (2010). Pre-learning low-frequency vocabulary in second language television programmes. Language Teaching Research, 14(4), 501-515. doi:10.1177/1362168810375371.

[57] Widdowson, H. G. (1983). Learning purposes and language use. Oxford, U.K: Oxford UP.

[58] Zemach, D. (2005). Interchange video activity book. Cambridge, U.K: Cambridge University Press.

Mandana Hazrat is an MA student studying TEFL at Payam -e- Noor University, Iran. She also teaches English at language institutes. Her research interests are vocabulary teaching and learning and teaching methodology. This manuscript is based on a thesis submitted by her in partial fulfillment of the requirements for the degree of Master of Arts in TEFL.

Gholamreza Hessamy is an associate professor of TEFL at Payam-e-Noor University, Iran. His research interests are language assessment, teaching methodology, and teaching language for academic purposes. 